\title{
Relation between Mechanical Properties and Microstructure of Cast Aluminum Alloy AISi9Cu3
}

\author{
M. Panušková, ${ }^{1, a}$ E. Tillová, ${ }^{1, b}$ and M. Chalupováa ${ }^{1, c}$ \\ ${ }^{1}$ University of Zilina, Faculty of Mechanical Engineering, Department of Materials Engineering, \\ Zilina, Slovak Republic \\ ${ }^{a}$ marta.panuskova@fstroj.uniza.sk, ${ }^{b}$ eva.tillova@fstroj.uniza.sk, \\ c maria.chalupova@fstroj.uniza.sk
}

\begin{abstract}
One common material for engine applications is the AlSi9Cu3 alloy. This alloy has a good castability, excellent machinability, medium strength, and low specific weight. The study was focused on the investigation of the effect of the solution heat treatment on the microstructure and mechanical properties of the alloy (strength $-R_{m}$, hardness - HBS). The temperatures of the solution heat treatment were $505^{\circ} \mathrm{C}, 515^{\circ} \mathrm{C}$, and $525^{\circ} \mathrm{C} \pm 5^{\circ} \mathrm{C}$ and the solution time ranged from 0 to $32 h(0,2,4,8,16$, and $32 \mathrm{~h})$. Alloy AlSi9Cu3 contained $\alpha$-matrix, eutectic silicon, and other Feand $\mathrm{Cu}$-rich phases with different morphology (needle-like, Chinese script, skeleton-like, blocky, etc.). The results obtained revealed the relation between the mechanical properties and the morphologies of the eutectic silicon and the predominant copper-rich phase $\mathrm{Al}-\mathrm{Al} \mathrm{I}_{2} \mathrm{Cu}-\mathrm{Si}$ during the solution treatment.
\end{abstract}

Keywords: aluminum cast alloys, microstructure, mechanical properties, intermetallic phases, fracture zones.

Introduction. In industry, particularly in aerospace and automobile branches, there is a tendency to reduce costs, prices, and weight of complete products. In this respect, of importance are easy availability and the industry requirements for environmental protection, i.e., recyclability of industry materials. Significant is the fact that the density of steel materials is three times higher than that of aluminum alloys. The substitution of aluminum alloys for magnesium ones is a momentous aim in the development of many branches of industry, but magnesium alloys have a lot of disadvantages: the contact with magnesium melts is hazardous that excludes their recycling possibilities [1].

Cost effectiveness of the production and application of aluminum alloys is being constantly improved, e.g., at present an average European automobile contains about $90 \%$ of recycled aluminum alloys out of the total share of aluminum alloys in an automobile [1]. Al-Si cast alloys are extensively used in the automotive and aerospace industries due to their excellent castability, good mechanical properties and wear resistance. The addition of alloying elements such as $\mathrm{Mg}$ and $\mathrm{Cu}$ make these alloys heat treatable further improving their mechanical properties and allowing their use in new, more demanding applications (e.g., engines, cylinder heads, etc.). The most used heat treatment for these $\mathrm{Al}-\mathrm{Si}-\mathrm{Cu}$ cast alloys is the solution treatment followed by age hardening that is required for the precipitation of the $\mathrm{Al}_{2} \mathrm{Cu}$ hardening constituent. The solution heat treatment of $\mathrm{Al}-\mathrm{Si}-\mathrm{Cu}$ cast alloys affects the microstructure of the alloy in three aspects, namely: the dissolution of coarse $\mathrm{Al}_{2} \mathrm{Cu}$, homogenization of the microstructure, improvement of eutectic silicon morphology (fragmentation, spheroidization, and coarsening), and the ensuing changes in the fracture zones [2].

The present study is a part of a larger research project, which was conducted to investigate and to provide a better understanding of the influence of heat treatment on the structure (structural analyses) and mechanical properties of cast $\mathrm{Al}-\mathrm{Si}-\mathrm{Cu}$ alloys. The study was conducted on the most popular AlSi9Cu3 alloy that contains about $9 \% \mathrm{Si}$ and $3 \% \mathrm{Cu}$. 


\begin{tabular}{|c|c|c|c|c|c|c|c|c|c|c|}
\hline T a b l e 1 & \multicolumn{10}{c}{ Chemical Composition of AlSi9Cu3 Alloy } \\
\hline Element & $\mathrm{Si}$ & $\mathrm{Cu}$ & $\mathrm{Mn}$ & $\mathrm{Zn}$ & $\mathrm{Mg}$ & $\mathrm{Ni}$ & $\mathrm{Pb}$ & $\mathrm{Fe}$ & $\mathrm{Ti}$ & $\mathrm{Al}$ \\
\hline wt. $\%$ & 10.7 & 2.4 & 0.22 & 1.1 & 0.27 & 0.08 & 0.11 & 0.9 & 0.03 & base \\
\hline
\end{tabular}

Experimental. Experiments were performed on AlSi9Cu3 cast alloy whose chemical composition is given in Table 1. This alloy has a lower corrosion resistance and is suitable for high-temperature (up to max. $250^{\circ} \mathrm{C}$ ) applications (dynamically exposed casts). In this case, the requirements to its mechanical properties are not so restrictive. This cast alloy was produced at the Foundry Co. CONFAL, a.s., Slovenská Lupca.

Alloys of the $\mathrm{Al}-\mathrm{Si}-\mathrm{Cu}$ type are usually heat treated in order to develop higher mechanical properties. Heat treatment involves solution and aging heat treatments during which a series of changes in microstructure occur which then lead to the improvement of strength. These changes in microstructure include the dissolution of precipitates, homogenization of the cast structure, such as minimization of alloying element segregation, spheroidization and coarsening of eutectic silicon, and precipitation of finer hardening phases $[3,4]$. Different solution heat treatment procedures were used to evaluate their influence on the mechanical properties (tensile strength, $R_{m}$, and hardness, $H B S$ ) and on the morphology of the eutectic $\mathrm{Si}$ and $\mathrm{Cu}$-rich phase (ternary eutectic $\mathrm{Al}-\mathrm{Al}_{2} \mathrm{Cu}-\mathrm{Si}$ phase) and on ensuing changes in the fracture pattern.

The experiments were carried out in an electric induction furnace. The castings were subjected to the solution treatment at three temperatures $\left(505,515\right.$, and $\left.525^{\circ} \mathrm{C}\right)$ during the periods of time ranging from 2 to 32 hours $(0,2,4,8,16$, and $32 \mathrm{~h})$, then quenched in warm water in the temperature range from 40 to $60^{\circ} \mathrm{C}$, and aged naturally at room temperature for 24 hours. The samples for microscopic analysis were prepared by standard metallographic procedures (wet ground, DP polished with diamond pastes and etched by Dix-Keller, $\mathrm{HNO}_{3}$ or MA [2]).

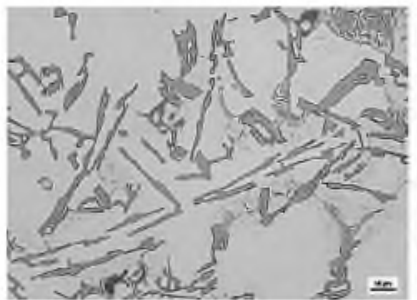

a

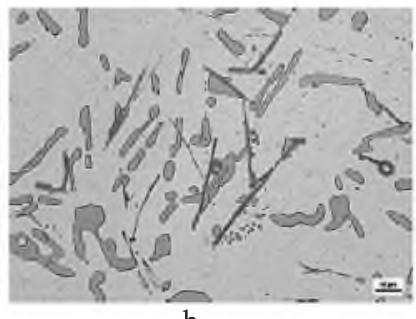

b

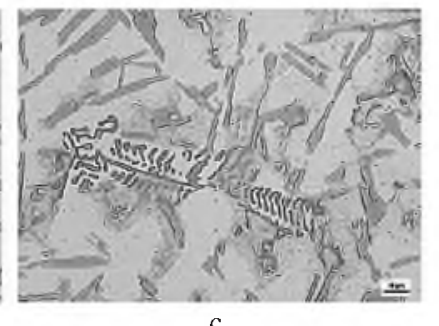

$\mathrm{c}$

Fig. 1. Typical microstructure patterns in AlSi9Cu3 cast alloy (etched by a Dix Keller solution): (a) $\alpha$-matrix, platelets of eutectic $\mathrm{Si}$; (b) $\mathrm{Al}_{5} \mathrm{FeSi}_{2} \mathrm{Al}-\mathrm{Al}_{2} \mathrm{Cu}-\mathrm{Si}$ phase; (c) $\mathrm{Al}_{15}(\mathrm{MnFe})_{3} \mathrm{Si}$ phase "Chinese script."

Generally, the as-cast microstructure of AlSi9Cu3 alloy comprises $\alpha$-matrix, the platelets of eutectic silicon (dark grey) (Fig. 1a) and many intermetallic phases. In this alloy there were also observed the following intermetallic phases: the iron phase $\mathrm{Al}_{5} \mathrm{FeSi}$ in the shape of black needles (Fig. 1b), which has a monoclinic crystal structure and precipitates in interdendritic and intergranular regions as platelets [5]. Long $\mathrm{Al}_{5} \mathrm{FeSi}$ platelets (more than $500 \mu \mathrm{m}$ ) can adversely affect the mechanical properties, especially ductility, and they also lead to the formation of excessive shrinkage porosity defects in castings. The $\mathrm{Al}_{5} \mathrm{FeSi}$ phase appears as a nucleation locality for $\mathrm{Cu}$-rich phase $\mathrm{Al}-$ $\mathrm{Al}_{2} \mathrm{Cu}-\mathrm{Si}$ (Fig. 1b).

Another common iron intermetallic is the $\mathrm{Al}_{15}(\mathrm{MnFe})_{3} \mathrm{Si}$ phase with a cubic crystal structure [6]. This phase has a compact morphology in the form of "Chinese script" 
(Fig. 1c) and thus it contains less initiated cracks as compared to the needle-like phase $\mathrm{Al}_{5} \mathrm{FeSi}$. The effect of the applied heat treatment on these iron-rich phases $\left(\mathrm{Al}_{5} \mathrm{FeSi}-16 \%\right.$ $\left.\mathrm{Fe}, \mathrm{Al}_{15}(\mathrm{MnFe})_{3} \mathrm{Si}-14 \% \mathrm{Fe}\right)$ is not significant and results only in partial segmentation of these phases. Half or more of copper is found as a component of intermetallic compounds, primarily, the $\mathrm{Al}_{2} \mathrm{Cu}$ phase with tetragonal crystal structure precipitates in two distinct morphologies: $\mathrm{Al}_{2} \mathrm{Cu}$ and in the form of blocky phase with a high copper concentration $\sim 38-40 \% \mathrm{Cu}$ (ternary eutectic $\mathrm{Al}-\mathrm{Al}_{2} \mathrm{Cu}-\mathrm{Si}-\mathrm{Fig}$. 2a). These compounds that form at the later stages of freezing are located in the interdendritic regions and at the grain boundaries. Gradual dissolving of the $\mathrm{Cu}$-rich phase occurs with increasing heat treatment temperature (Fig. 2) and this fact is also confirmed by harness measurement results.

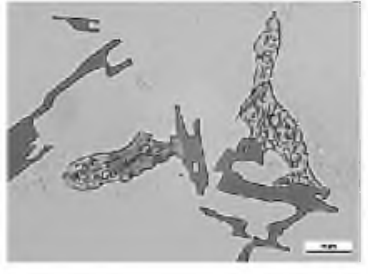

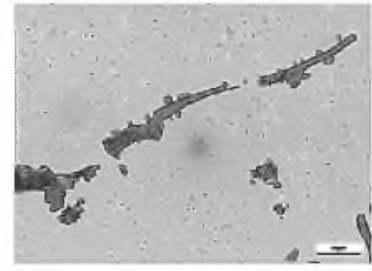

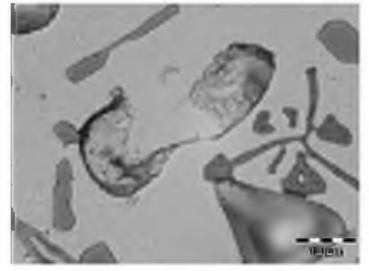

Fig. 2. The influence of heat treatment on the morphology of the $\mathrm{Al}-\mathrm{Al}_{2} \mathrm{Cu}-\mathrm{Si}$ phase: (a) untreated; (b) at $515^{\circ} \mathrm{C} / 4$ hours; (c) at $525^{\circ} \mathrm{C} / 4$ hours.

The improvement of the eutectic silicon morphology and its distribution have the most significant influence on the changes in the mechanical properties (Fig. 3). The morphology of the eutectic silicon not subjected to heat treatment has the shape of platelets (Fig. 3a). Figure 3b-d demonstrates changes in the eutectic Si morphology caused by the solution treatment with a holding time of 8 hours. At temperatures of 505 and $515^{\circ} \mathrm{C}$ gradual spheroidization of the eutectic Si particles begins (Fig. $3 \mathrm{~b}$ and c). As the solution treatment continued to the temperature $525^{\circ} \mathrm{C}$, the spheroidized particles gradually grew larger (overcoarsed) (Fig. 3d).

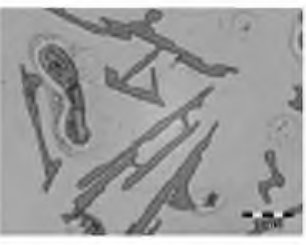

a

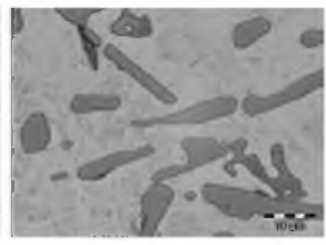

b

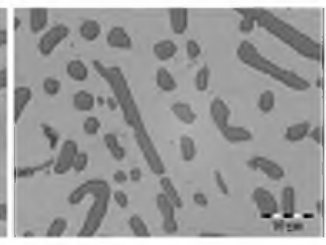

$c$

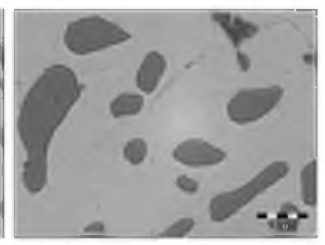

d

Fig. 3. Changes in the eutectic silicon morphology during heat treatment: (a) untreated; (b) heat treated at $505^{\circ} \mathrm{C}$ during 8 hours; (c) heat treated at $515^{\circ} \mathrm{C}$ during 8 hours; (d) heat treated at $525^{\circ} \mathrm{C}$ during 8 hours.

These changes in the eutectic Si influence the the characterpattern of the fracture zones as well. In the eutectic silicon not subjected to the solution treatment, brittle fracture fragile breach of the eutectic platelets and ductile failure of the $\alpha$-matrix are observed. With gradual spheroidization of the eutectic $\mathrm{Si}$, the share of the ductile failure in the alloy increases.

The microstructure of AlSi9Cu3 alloy is a reflection of the mechanical properties (Fig. 4). The increase in the strength and hardness values is significant chiefly for temperatures of 505 and $515^{\circ} \mathrm{C}$ and for holding time of 8 hours at the most. By the eighth hour of the holding time the values of the mechanical properties (chiefly $H B S$ ) begin to decrease. This trend is typical for all solution heat treatment temperatures and relates to 
gradual coarsening of the eutetectic Si for the hold time longer than 8 hours (Fig. 4). At the a temperature of $525^{\circ} \mathrm{C}$ a decrease in the values of the mechanical properties is observed due to a significant coarsening of the eutectic Si (Fig. 3d).
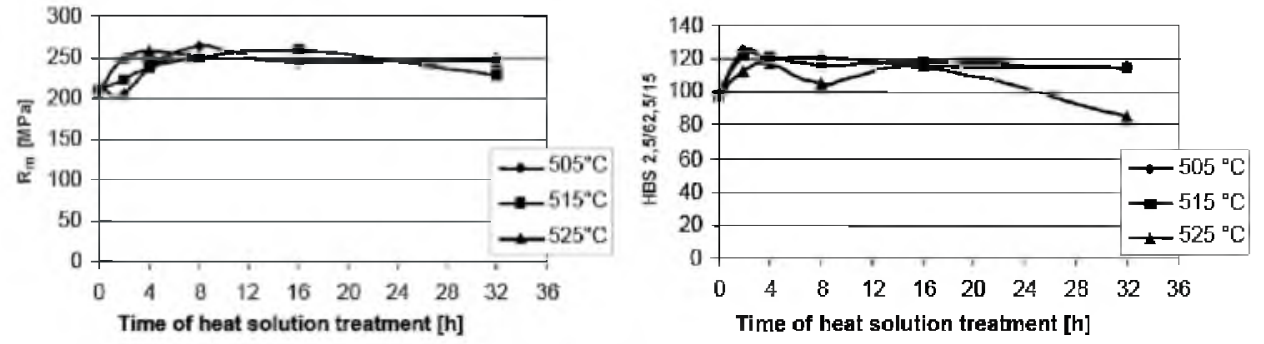

Fig. 4. Changes in the mechanical properties of AlSi9 $\mathrm{Cu} 3$ alloy during heat treatment.

With a deincrease in the heat treatment temperatures, gradual dissolution of the $\mathrm{Cu}$-rich phase takes place and this fact also confirms the results obtained for hardness and tensile strength. With an increase in the solution treatment temperature, the hardness and strength values increase to a maximum value at $515^{\circ} \mathrm{C}$ and then decrease. Hardness correlates withis a reflection of the solution strengthening and silicon particle distribution in the matrix. Temperature $515^{\circ} \mathrm{C}$ is a suitable appropriate temperature for this alloy. Below this temperature, the solutionization process is insufficient, whereas above it, overcoarsening of the $\mathrm{Si}$ particles and melting of $\mathrm{Al}_{2} \mathrm{Cu}$ melting $\mathrm{Al}_{2} \mathrm{Cu}$ occurs. These two unsatisfied conditionsaspects all result in the reduction of hardness and strength.

Conclusions. The contribution investigation was focused on the influence of the solution heat solution treatment on the microstructure and mechanical properties $\left(R_{m}\right.$ and $H B S$ ) of aluminum cast alloy AlSi9Cu3 for automotive applications. As shown by a the results shown, the optimaoptimuml conditions of the heat solution heat treatment for this alloy is are the temperature $515^{\circ} \mathrm{C}$ and holding time max. 8 hours. The changes of in the microstructure confirmed that these outcomes. A heat treatment by temperature of heat treatment $525^{\circ} \mathrm{C}$ get leads to gradual coarsening of the eutectic $\mathrm{Si}$, decreasing ofing of the values of the mechanical properties, values and dissolving dissolution of the ternary eutectic $\mathrm{Al}-\mathrm{Al}_{2} \mathrm{Cu}-\mathrm{Si}$.

Acknowledgments. The authors acknowledge the VEGA No. 1/2090/05 and No. 1/3153/06 for the financial support of this work.

1. J. Högerl, "Beeinflussung der Gefügemorphologie und der mechanischen Eigenschaften von AlSi7Mg-Legierungen," in: Fortschritt-Berichte VDI, Reihe 5, No. 457, VDI Verlag. Düsseldorf (1996).

2. C. Kammer, Aluminium-Taschenbuch, Band 1: Grundlagen und Werkstoffe, Auflage 15. Aluminium Verlag, Düsseldorf, (1995).

3. M. Kiš and P. Skočovský, "Structure analysis of Sr modified AlSi10MgMn alloy," in: Metody Oceny Struktury Oraz Wlasnosci Materialow i Wyrobow, Ustron-Jaszowiec, Wyd. Pol. Opolskiej, Poland (2005), pp. 89-94.

4. E. Tillová, M. Panušková, and M. Chalupová, "Influence of the solution treatment on the structure and properties of cast AlSi9Cu3 alloys," in: Fraktography'06, Star6 Lesn6 (2006), pp. 493-496.

5. E. Tillová, M. Panušková, and M. Chalupová, "Metallograpische Analyse von Al-Si-Cu Gusslegierungen," Berichte und Informationen, 2/2006, 14, Dresden, SRN (2006), pp. 49-55.

6. C. T. Rios and R. Caram, "Intermetallic compounds in the $\mathrm{Al}-\mathrm{Si}-\mathrm{Cu}$ system," Acta Mikroskopica, 12, No. 1, 77-81 (2003).

Received 28. 06. 2007 